\title{
Japan plans furnace reactor to consume Soviet plutonium
}

Tokyo. Japan hopes to use its investment in the development of fast-breeder reactors to dispose of plutonium left by the dismantling of nuclear weapons in the former Soviet Union.

Japan is trying to interest Western nations and Russia in a plan to burn up in a giant 'plutonium furnace' reactor one hundred or so tons of plutonium taken from dismantled Soviet weapons. Japan would use its expertise in fast-breeder technology, which uses plutonium as fuel, to design the reactor and would ask Western industrial nations to help build it in Russia.

Government officials have been quietly talking about the idea since April to representatives from other countries. They persuaded the seven industrial nations (Japan, United States, United Kingdom, Canada, France, Germany, and Italy) meeting earlier this month in Munich to include it in a statement calling for the group to help Russia dismantle its nuclear weapons.

Japan is one of the few advanced nations that have continued to pursue the development of fast-breeder reactors since the technology was developed in the $1950 \mathrm{~s}$. The government and industry have invested $¥ 600$ billion (US $\$ 4.8$ billion) in the construction of a prototype breeder reactor to begin operations in the next few months. But it will be decades before Japan is ready to build commercial breeder reactors.

The proposed plutonium furnace reactor differs from a breeder reactor in that it does not produce more plutonium, but their fundamental designs are similar. The breeder reactor has a core of plutonium/uranium

fuel surrounded by a blanket of uranium. Bombarding the uranium blanket with neutrons from the core creates new plutonium. The furnace reactor would lack the uranium blanket and thus not generate plutonium. However, both have a liquid-sodium cooling system that transports the vast amounts of heat produced by the plutonium/uranium core to its generators.

The Power Reactor and Nuclear Fuel Development Corporation (PNC), which is affiliated with the Science and Technology Agency (STA), has begun preliminary design work, and STA officials plan to make a request next month for money in fiscal year 1993. Quite apart from applying the technology to dispose of waste, PNC would like to develop plutonium furnace reactors that can consume the vast amounts of plutonium that Japan will have by early next century.

In the autumn, Japan will begin shipping plutonium, derived from spent Japanese nuclear fuel, back from reprocessing plants in Europe. By 2010, the government estimates it will have some 80 tons (see Nature 352, 7; 1991).

Japan is considering furnaces reactors of $800 \mathrm{MW}$ and 1,300 MW; two of the larger reactors could use up all the plutonium from former Soviet nuclear weapons in about 30 years and produce enough electricity to power a medium-sized city. But Toichi Sakata of STA's nuclear fuel division estimates that it will be "at least ten years" before a reactor is operating. The United States and most nuclear nations are concerned that the disposal of nuclear weapons materials threatens wglobal security.

David Swinbanks

\section{NEWS IN BRIEF}

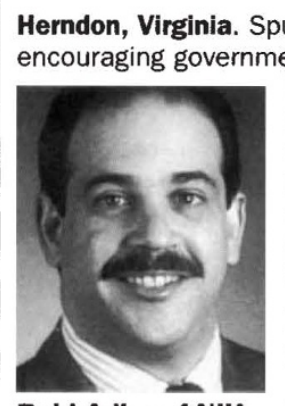

Reid Adler of NIH urred by new laws scientists to license their research, technology transfer is the fastest-growing area within US science agencies. One sign is a new organization - the Association of Federal Technology Transfer Executives - that aims to help its members to

learn the latest techniques.

The job can be controversial, as one of the association's founders - Reid Adler, the director of the technology transfer office at the National Institutes of Health (NIH) learned after he persuaded his agency to file applications for patents on gene fragments identified last year by $\mathrm{NIH}$ scientists. Although the Bush administration has backed $\mathrm{NIH}$, the case illustrates the continuing debate that surrounds the commercialization of government research. The new association held its first meeting earlier this month.

C.A.

Washington. Mission controllers have turned off the last operating transmitter aboard Magellan, in orbit around Venus, after its degrading signal became close to unusable. The probe, which has mapped more than 97 per cent of the planet since it reached it in 1990 , first had trouble with its main data transmitter more than a year ago. Its backup transmitter will be turned on briefly in September to map an area in Venus's southern latitudes, amounting to about 1.5 per cent of the planet's surface, that has never been mapped before.

C.A.

\section{University officials dismiss quick payoff from research funds}

Washington. A US presidential science advisory panel writing a report on the health of academic research was warned last week that science is hurt by exaggerated claims about the economic benefits of research.

Six years after a similar federal report extolled the payoff from basic research, politicians and the public assume that having a research centre in their neighbourhood will bolster local prosperity, said Robert Rosenzweig, president of the Association of American Universities, a consortium of 58 research universities in the United States and Canada. Such attitudes, he added, have also indirectly contributed to the growing number of research projects funded in the home districts of legislators without having received any formal peer review.

"It is now widely believed...that science and technology are the keys to local and regional economic development in the short run", Rosenzweig testified, adding that the half-a-billion dollars that the US Congress spent last year on so-called porkbarrel research projects is a monument to this belief. As research grows and funding stagnates, he said, "the political forces for wider distribution are so strong that program resources will be spread ever thinner, making concentrations of quality harder to sustain".

The hearing on 24 July, one of six held around the country in recent weeks, gave members of the academic community a chance to talk about their university's relationship with the federal government. It was convened by the President's Council of Advisors on Science and Technology (PCAST), which will use the testimony to prepare a report due out by the end of the year.

APCAST member, Harold Shapiro, president of Princeton University and moderator for the day-long hearing, agrees with Rosenzweig that the dollar-value of academic research to the surrounding community has been exaggerated. "Some universities oversold the benefits [of research] to local constituencies," he says, adding that such boosterism may now "turn on us" when those laboratories fail to come up quickly with commercial products.

PCAST's predecessor, the White House Science Council, produced a similar document in 1986 for the federal Office of Science and Technology Policy that recommended bigger budgets and less regulation of science. But PCAST members believe that the climate has changed dramatically as the recession and the enormous federal deficit jeopardize the continued growth of research budgets. 